\title{
衝突海難事故における人的エラーの数量化
}

\author{
竹本孝弘 ${ }^{*}$ 阪本義治 ${ }^{*} \cdot$ 古莊雅生 ${ }^{* *} \cdot$ 嶋田博行 ${ }^{* *}$
}

\section{Quantification of Human Error Occurred in Marine Collision Accidents}

\author{
Takahiro TAKEMOTO, Yoshiharu SAKAMOTO, \\ Masao FURUSHO and Hiroyuki SHIMADA
}

\begin{abstract}
It is said that marine accident caused by human error of ship's navigator in terms of mistake to look out, unusual maneuver is account for about $80 \%$ of the total accident. As the process of error caused accident is diverse, we have to research how navigator makes an error, as the result of that, how its error cause marine collision accidents to build an effective prevent measure against accidents. The authors established the classification model of human error on marine collision accidents to clear the dangerous factor behind an error based on the analysis of human error occurred in marine collision accident being included the book judging marine accidents. The authors made clear the relation among factors on the error rising process by making use of the accident analysis using the classification model which the authors established and reported.

This time, the authors conducted the error analysis using Quantification Method which is one of the measures for Multivariate Analysis. At the same time the authors researched the clue of making guideline which is needed to conduct safety navigation for vessels by trying to grasp both each compositions of factor and total image of error.
\end{abstract}

Keywords : Accident analysis, Marine collision accidents, Human error, Human factors, Quantification Method キーワード:事故解析、衝笑海難、人的エラー、人的要因、数量化而類

\section{1. はじめに}

「見張り不十分」、「操船不適切」という“操船者 の人的エラー”(以降「エラー」という)による海難 事故は、事故全体の約 8 割を占めると言われている。 事故に至ったエラーの発生形態は多岐にわたり、有 効な事故防止対策を構築するために、操船者はどの ようなときにエラーを犯し、それがどのように衝突 海難事故に結びついているかを探る必要がある。

筆者等は、海難審判裁決例集から衝突海難事故に おけるエラー発生形態の分析を基にエラーの背後 にある潜在的な危険要因を明らかにするための事
故分類法を構築した(1)。そして、構築した分類法を 用いた事故分析により、エラー発生過程におけるそ れぞれの要素間のつながりを解明し既に報告(2)した。 今回は、多変量解析の一手法である数量化類を用 いたエラー分析を行い、エラーの全体像と個々の要 素構成の把握を試み、船舶の安全運航に必要な船橋 当淔実務指針の手がかりを探った。

\section{2. 衝突海難事故における人的エラ一}

エラーによる衝突海難事故は突発的に発生するも のではなく、エラーのきっかけに始まり、操船者の

\footnotetext{
* 正会員 独立行政法人 航海訓練所(T243-0003 横浜市中区北仲通 5-57)
}

** 正会員 神户大学海事科学部(产658-0022 神戸市東灘区深江南町 5-1-1) 
情報処理系にさまざまな内的要因や外部環境が作 用し、最終的に操船者が誤つた操船を行い事故に至 ると考えられる。そこで、エラ一の発生過程を、入 力 (エラーのきつかけ) と出力 (行動·動作) とい う観点から、1.「エラーをもたらした原因(エラーの きっかけ)」、2．「エラーのメカニズム(操船者の行動 パタン)」、3.「エラーに至った内的要因(操船者の情 報処理過程でのエラー)」、4.「外観的エラーモード (最終的な事故原因)」及び 5.「パフォーマンスに影 響する因子」の 5 つの要素に分類した。それぞれの 要素について衝突海難事故における具体的な細目 を決定することにより、事故を分析するうえで標準
的に適用できる事故分類法を構築した(1)。その概念 図を Fig. 1 に示す。

\section{3. 数贯化 III類}

さまざまな要素が複雑に絡み合っている問題のひ とつひとつの要素を数值で表し、その要素から本質 的な部分を抽出して評価することを数量化という(3)。 数量化III類は Fig. 2 に示すように外的な基準が全く 与えられていないときに、2つの変量の相関を最も 強くするように変量の順序を入れ替えることによっ て変量に順位を与える方法である。Fig. 2 の X 項目 をサンプル、Y 項目をカテゴリーという。

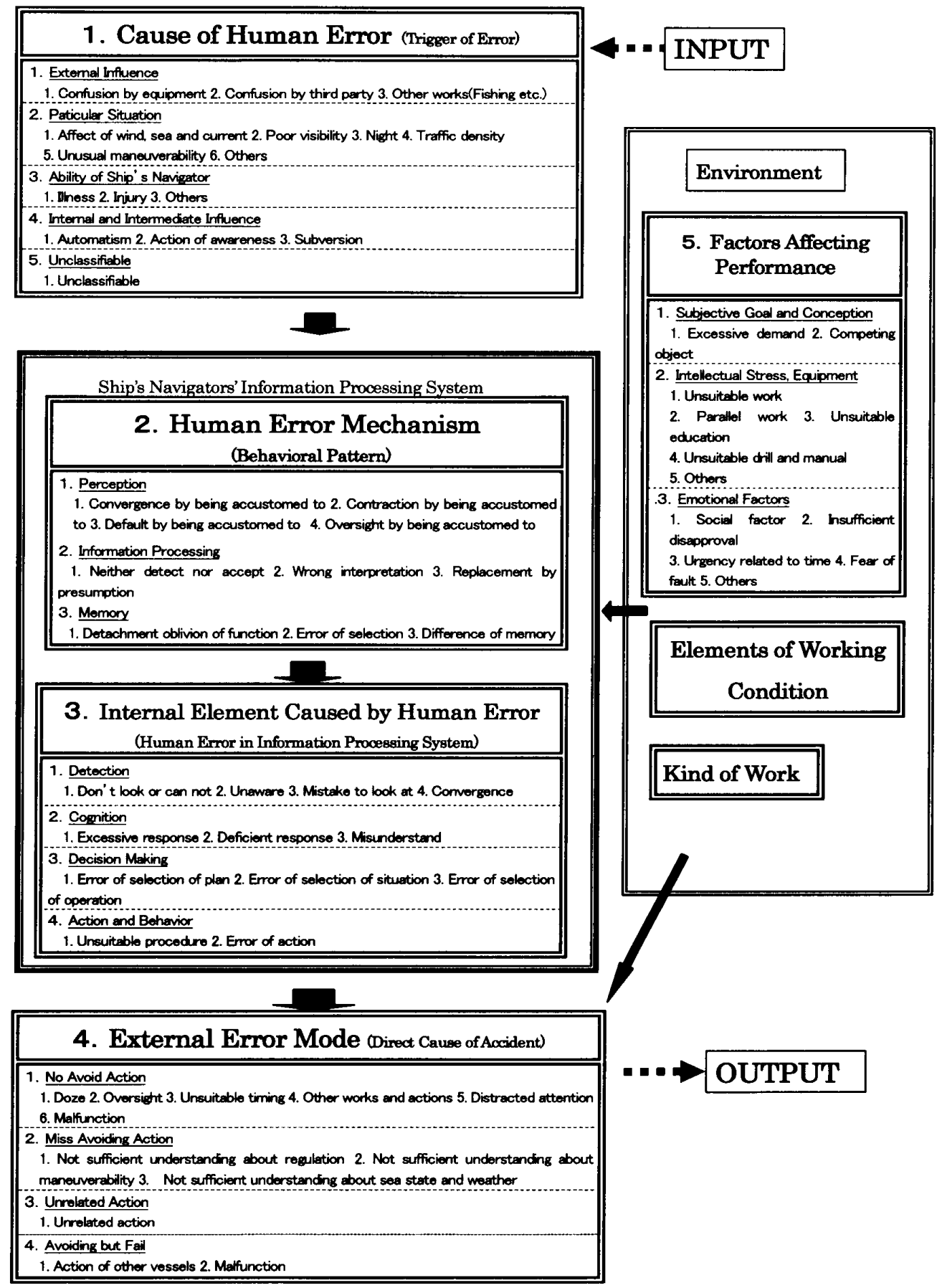

Fig. 1 Classification model of marine collision accident 


\section{4. 人的エラーの数典化而類による分析}

分類法を使用して要素ごとに分類した分析データ は、海難審判裁決例集 ${ }^{(4)}$ に記載された 96 件、190 隻の衝突事故事例で、前報(2)で使用したデータと同 一である。

数量化 III 類におけるカテゴリーは事故分類法の要 素及びその細目を示し、分析ソフト(JUSE 統計パッ ケージStat Master)を使用して各カテゴリーの成分 ごとのスコアを求めた。主成分は第 3 まで求め、各 成分をX軸及びY軸としたカテゴリープロットを作

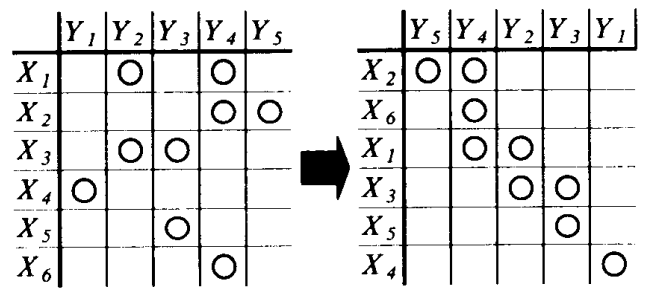

Fig. 2 Concept of the Quantification Method IIl
図した。相関の強いカテゴリーはカテゴリープロッ ト上で近接して表示される。

今回は前報(2) の調查で事故原因として特に多か った「注意散漫」(96 件の事故例の約 37\%を占める) 及び「不適当なタイミング」（同 $25 \%$ )による事故を 数量化而類により分析した。カテゴリー名は事故分 類法の各要素及び細目を番号で示し、例えば分類法 の要素 1 「人的エラーをもたらした原因」の細目 1

「外的な事柄」、1「機器による混乱」であればカテ ゴリー名は[1.1.1]となる。

\section{1 注意散温による事故}

注意散漫による衝突事故とは、操船者が他船の動 静に十分な注意を払わず、そのために適切な操船を 行わず衝突した場合である。

注意散漫による事故を数量化而類により分析し、 成分 1 から成分 3 までのカテゴリープロットを Fig. 3 に示す。また、プロット上で近接している $\mathrm{A} \sim \mathrm{Q}$

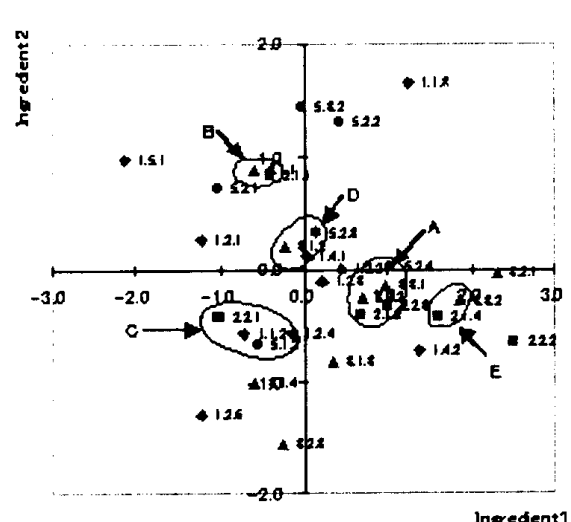

Ingredient 1 and 2

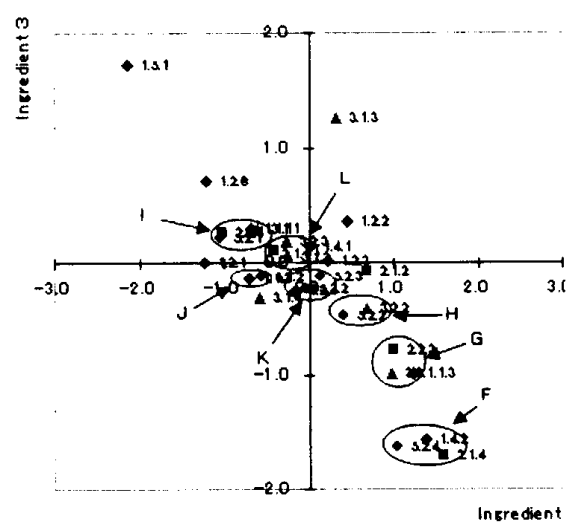

Ingredient 1 and 3

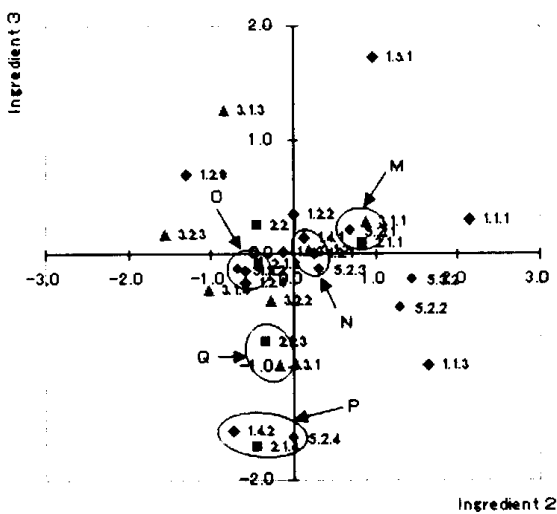

Ingredient 2 and 3

Fig. 3 Category plot of the accident caused by distracted attention

Table 1 Category score of the accident caused by distracted attention

\begin{tabular}{|c|c|c|c|}
\hline Group & Cateron & Inrredient 1 & Inredient 2 \\
\hline \multirow{5}{*}{ A } & 2.1 .2 & 0.674 & -0.414 \\
\hline & 2.2 .3 & 0.995 & -0.338 \\
\hline & 3.2 .2 & 0.691 & -0.268 \\
\hline & 3.3 .1 & 0.972 & -0.158 \\
\hline & & 1.037 & 0.010 \\
\hline \multirow{3}{*}{ B } & 2.1 .1 & -0.409 & 0.836 \\
\hline & 3.1 .1 & -0.597 & 0.883 \\
\hline & 1.1 .2 & -0.712 & -0.579 \\
\hline \multirow{3}{*}{ C } & 1.2 .4 & -0.150 & -0.581 \\
\hline & 2.2 .1 & -1.011 & -0.437 \\
\hline & & -0.553 & -0.670 \\
\hline \multirow{3}{*}{ D } & 1.41 & 0.014 & 0.119 \\
\hline & 312 & -0.235 & 0.194 \\
\hline & 5.23 & 0.140 & 0.324 \\
\hline \multirow{2}{*}{$E$} & 2.1 .4 & 1.598 & -0.439 \\
\hline & 3.3.2 & 1.866 & -0.288 \\
\hline
\end{tabular}

Ingredient 1 and 2

\begin{tabular}{|c|c|c|c|}
\hline Group & Categon & Engredient 1 & Inredient 3 \\
\hline & 1.42 & 1.383 & -1.556 \\
\hline \multirow[t]{2}{*}{$\mathrm{F}$} & 2.1 .4 & 1.598 & -1.696 \\
\hline & 5.24 & 1.037 & -1.629 \\
\hline \multirow{3}{*}{ G } & 1.1 .3 & 1.238 & -0.984 \\
\hline & 2.2 .3 & 0.995 & -0.774 \\
\hline & $3,3.1$ & 0.972 & -0.987 \\
\hline \multirow{2}{*}{ H } & 3.2 .2 & 0.691 & -0.419 \\
\hline & 5.2 .2 & 0.412 & -0.479 \\
\hline \multirow{4}{*}{1} & 1.1 .1 & -0.694 & 0.297 \\
\hline & 2.2 .1 & -1.011 & 0.252 \\
\hline & 3.1.1 & -0.597 & 0.283 \\
\hline & 5.2 .1 & -1.042 & 0.207 \\
\hline \multirow{2}{*}{$J$} & 1.1 .2 & -0.712 & -0.151 \\
\hline & 5.1 .2 & -0.553 & -0.133 \\
\hline \multirow{3}{*}{ K } & 1.2 .4 & -0.150 & -0.258 \\
\hline & 5.2 .3 & 0.140 & -0.139 \\
\hline & 5.3 .2 & -0.023 & -0.238 \\
\hline \multirow{4}{*}{ L } & $1 / 41$ & 0.014 & 0.141 \\
\hline & 2.1 .1 & -0.409 & 0.100 \\
\hline & 3,12 & -0.235 & 0.036 \\
\hline & 3.2 .3 & -0.259 & 0.179 \\
\hline
\end{tabular}

Ingredient 1 and 3

\begin{tabular}{|c|c|c|c|}
\hline Grous & Cateron & Inredient 2 & Ingredient 3 \\
\hline & 2.1 .1 & 0.836 & 0.100 \\
\hline \multirow[t]{2}{*}{$M$} & $3,1.1$ & 0.883 & 0.283 \\
\hline & 5.2 .1 & 0.697 & 0.207 \\
\hline \multirow{4}{*}{$\mathbf{N}$} & 1.2 .1 & 0.260 & -0.003 \\
\hline & 1.4 .1 & 0.119 & 0.141 \\
\hline & 3.1 .2 & 0.194 & 0.036 \\
\hline & 5.2 .3 & 0.324 & -0.139 \\
\hline \multirow{4}{*}{0} & 1.1 .2 & -0.579 & -0.151 \\
\hline & 1.2 .4 & -0.581 & -0.258 \\
\hline & 2.1 .2 & -0.414 & -0.087 \\
\hline & 5.1 .2 & -0.670 & -0.133 \\
\hline \multirow{3}{*}{$P$} & 1.42 & -0.728 & -1.556 \\
\hline & 21.4 & -0.439 & -1.696 \\
\hline & 52.4 & 0.010 & -1.629 \\
\hline \multirow{2}{*}{$Q$} & $2.2,3$ & -0.338 & -0.774 \\
\hline & 3.3 .1 & -0.158 & -0.987 \\
\hline
\end{tabular}

Ingredient 2 and 3 
のカテゴリーグループを抽出し、そのグループのカ テゴリースコアを Table 1 に示す。

\section{2 不薏当なタイミングによる事故}

不適当なタイミングによる衝突事故とは、他船と の衝突のおそれに気付いているにもかかわらず、避 航の時機を逸したために衝突した場合である。

不適当なタイミングによる事故を数量化而類によ り分析し、成分 1 から成分 3 までのカテゴリープロ ットを Fig. 4 に示す。また、プロット上で近接して いる $\mathrm{A} \sim \mathrm{R}$ のカテゴリーグループを抽出し、そのグ ループのカテゴリースコアを Table 2 に示す。

\section{5. 考的}

エラー発生過程における各要素を構成する細目 （カテゴリー）の相関は、数量化而類による分析に基 づいて判断できる。今回分析した「注意散漫による 事故」については $\mathrm{A} \sim \mathrm{Q}$ 、「不適当なタイミングによ る事故」については $\mathrm{A} \sim \mathrm{R}$ の近接したグループを抽
出した。各グループの標準偏差は Table 3 及び Table4 に示すとおりで、分散は非常に小さく、グル 一プ内のカテゴリーが強い相関を持つことが分かる。 この二つのタイプの事故について、抽出したカテ ゴリーグループから事故と操船者エラーの関係につ いて考察する。

\section{1 注意散瀑による事故と操船者エラ一}

抽出した各カテゴリーグループに含まれるカテゴ リーが相互に結びついて、事故に至る操船者エラー が発生していると考えることができる。特に次の1 〜(4)のカテゴリーの組み合わせは、複数の抽出した カテゴリーグループに含まれており(Table 1 の網掛 け)、事故と相関が特に強いと思われる。

\section{(1) $\{2.1 .1,3.1 .1\}$}

[2.1.1]は要素 2 「人的エラーのメカニズム」、細目 1「識別」.1「慣れによる一点集中」を、[3.1.1]は要 素 3「人的エラーに至った内的要因」、細目 1「検

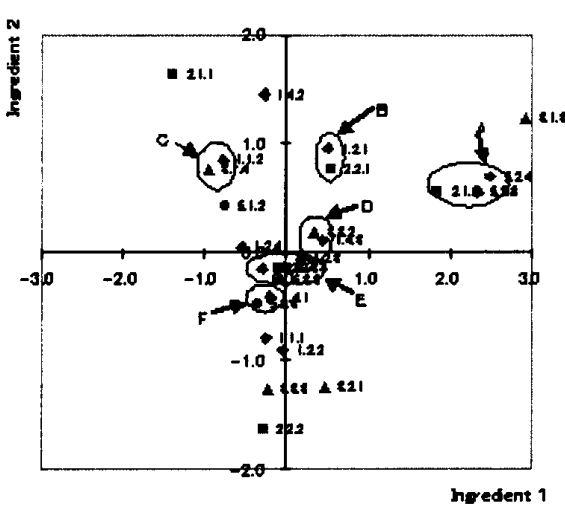

Ingredient 1 and 2

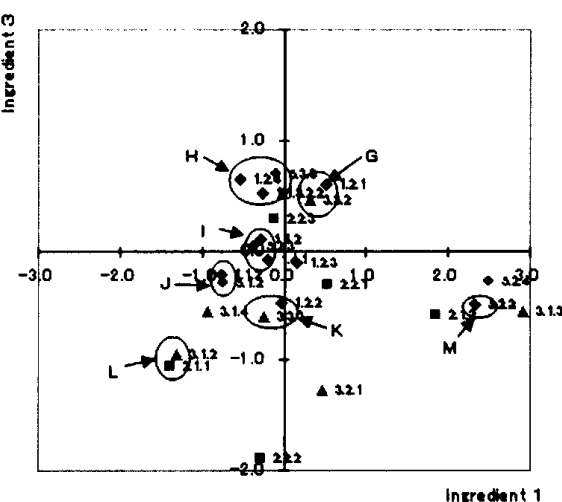

Ingredient 1 and 3

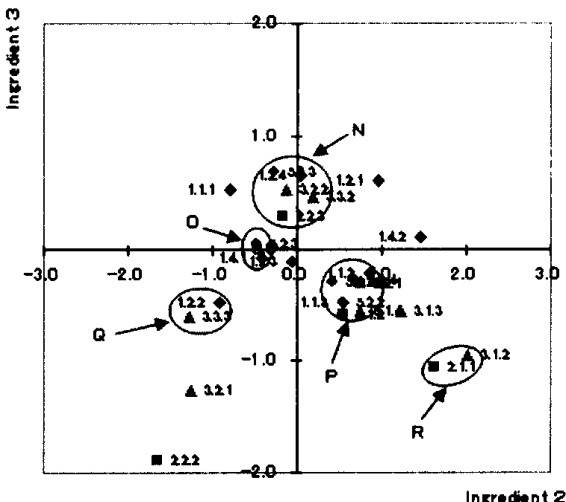

Ingredient 2 and 3

Fig. 4 Category plot of the accident caused by unsuitable timing

Table 2 Category score of the accident caused by unsuitable timing

\begin{tabular}{|c|c|c|c|}
\hline Grow: & attron & Wirogont & Worocinat \\
\hline \multirow{4}{*}{ A } & 1.1 .3 & 2.334 & 0.552 \\
\hline & 2.1 .2 & 1.849 & 0.549 \\
\hline & 5.2 .2 & 2.334 & 0.552 \\
\hline & 5.2 .4 & 2.502 & 0.680 \\
\hline \multirow{2}{*}{ B } & 1.2 .1 & 0.512 & 0.960 \\
\hline & 2.2 .1 & 0.537 & 0.746 \\
\hline \multirow{2}{*}{ C } & 1112 & -0.773 & 0.845 \\
\hline & $\frac{164}{314}$ & -0.937 & 0.754 \\
\hline \multirow{2}{*}{ D } & 1.4 .3 & 0.431 & 0.113 \\
\hline & 3.3 .2 & 0.326 & 0.195 \\
\hline \multirow{5}{*}{$\mathbf{E}$} & 1.2 .3 & 0.163 & -0.068 \\
\hline & 1.2 .6 & -0.289 & -0.163 \\
\hline & 228 & -0.107 & -0.163 \\
\hline & 322 & -0.014 & -0.123 \\
\hline & 5.38 & -0.094 & -0.272 \\
\hline \multirow{2}{*}{$F$} & 1.4 .1 & -0.201 & -0.421 \\
\hline & 5.2 .3 & -0.356 & -0.477 \\
\hline
\end{tabular}

\begin{tabular}{|c|c|c|c|}
\hline E.0.2 & Cuteron: & Hasodienter & Lanedient 3 \\
\hline \multirow{2}{*}{ G } & 1.2 .1 & 0.512 & 0.594 \\
\hline & 3.3 .2 & 0.326 & 0.461 \\
\hline \multirow{4}{*}{ H } & 1.1 .1 & -0.255 & 0.522 \\
\hline & 1.2 .4 & -0.536 & 0.641 \\
\hline & 322 & -0.014 & 0.524 \\
\hline & 50.23 & -0.094 & 0.684 \\
\hline \multirow{3}{*}{1} & 1.4 .1 & -0.201 & -0.081 \\
\hline & 1.4 .2 & -0.272 & 0.103 \\
\hline & 5.2 .3 & -0.356 & 0.039 \\
\hline \multirow{2}{*}{$J$} & 1.1 .2 & -0.773 & -0.228 \\
\hline & 5.1 .2 & -0.748 & -0.308 \\
\hline \multirow{2}{*}{ K } & 1.2 .2 & -0.032 & -0.494 \\
\hline & 3.3 .3 & -0.238 & -0.611 \\
\hline \multirow{2}{*}{ L } & प्रा1 & -1.382 & -1.060 \\
\hline & 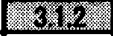 & -1.306 & -0.951 \\
\hline \multirow[t]{2}{*}{ M } & 1.1.3 & 2.334 & -0.498 \\
\hline & 5.2 .2 & 2.334 & -0.498 \\
\hline
\end{tabular}

Ingredient 1 and 3

\begin{tabular}{|c|c|c|c|}
\hline Words? & Crts or & 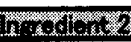 & WWLEN \\
\hline \multirow{5}{*}{$\mathbf{N}$} & 1.2 .4 & 0.050 & 0.641 \\
\hline & 296 & -0.163 & 0.292 \\
\hline & 301 & -0.123 & 0.524 \\
\hline & 3.3 .2 & 0.195 & 0.461 \\
\hline & $5 \times 1$ & -0.272 & 0.684 \\
\hline \multirow{2}{*}{0} & 1.4 .1 & -0.421 & -0.081 \\
\hline & 5.2 .3 & -0.477 & 0.039 \\
\hline \multirow{8}{*}{$\mathbf{P}$} & 91.2 & 0.845 & -0.228 \\
\hline & 1.1 .3 & 0.552 & -0.498 \\
\hline & 2.1 .2 & 0.549 & -0.597 \\
\hline & 2.2 .1 & 0.746 & -0.321 \\
\hline & 3.14 & 0.754 & -0.570 \\
\hline & 5.1 .2 & 0.421 & -0.308 \\
\hline & 5.2 .2 & 0.552 & -0.498 \\
\hline & 5.2 .4 & 0.680 & -0.283 \\
\hline \multirow{2}{*}{$Q$} & 1.2 .2 & -0.911 & -0.494 \\
\hline & 3.3.3 & -1.262 & -0.611 \\
\hline \multirow{2}{*}{$\mathbf{R}$} & $2 \pi, 11$ & 1.627 & -1.060 \\
\hline & 0.12 & 2.026 & -0.951 \\
\hline
\end{tabular}

Ingredient 2 and 3 
Table 3 Standard deviation of category group (Distracted attention)

\begin{tabular}{c|c|c|c}
\hline Group & ngredient & ingredient & ingredient 3 \\
\hline A & 0.158 & 0.148 & - \\
\hline B & 0.094 & 0.024 & - \\
\hline C & 0.311 & 0.083 & - \\
\hline D & 0.156 & 0.085 & - \\
\hline$E$ & 0.134 & 0.076 & - \\
\hline F & 0.231 & - & 0.057 \\
\hline$G$ & 0.120 & - & 0.100 \\
\hline$H$ & 0.140 & - & 0.030 \\
\hline$I$ & 0.194 & - & 0.035 \\
\hline$J$ & 0.079 & - & 0.009 \\
\hline$K$ & 0.119 & - & 0.052 \\
\hline$L$ & 0.152 & - & 0.053 \\
\hline$M$ & - & 0.079 & 0.075 \\
\hline$N$ & - & 0.076 & 0.100 \\
\hline$O$ & - & 0.092 & 0.063 \\
\hline$P$ & - & 0.304 & 0.057 \\
\hline$Q$ & - & 0.090 & 0.106 \\
\hline
\end{tabular}

Table 4 Standard deviation of category group (Unsuitable timing)

\begin{tabular}{c|c|c|c}
\hline Group & ngredient & ngredient & ingredient 3 \\
\hline A & 0.244 & 0.056 & - \\
\hline B & 0.013 & 0.107 & - \\
\hline C & 0.082 & 0.045 & - \\
\hline D & 0.052 & 0.041 & - \\
\hline E & 0.147 & 0.067 & - \\
\hline F & 0.078 & 0.028 & - \\
\hline G & 0.093 & - & 0.067 \\
\hline H & 0.200 & - & 0.071 \\
\hline I & 0.063 & - & 0.076 \\
\hline J & 0.013 & - & 0.040 \\
\hline K & 0.103 & - & 0.058 \\
\hline L & 0.038 & - & 0.054 \\
\hline M & 0.000 & - & 0.000 \\
\hline N & - & 0.165 & 0.139 \\
\hline O & - & 0.028 & 0.060 \\
\hline P & - & 0.132 & 0.134 \\
\hline Q & - & 0.176 & 0.058 \\
\hline$R$ & - & 0.200 & 0.054 \\
\hline & & &
\end{tabular}

出」.1「見ず、見えず」を示す。

操船者が他船を識別する際に“いつものように衝 突のおそれのある他船はいないだろう”とスキルべ 一スで臆断して見張りを态り、その結果他船との衝 突のおそれを検出せずに事故に至る場合である。

\section{(2) $\{2.2 .3,3.3 .1\}$}

[2.2.3]は要素 2 「人的エラーのメカニズム」、細目 2 「入力情報の処理」.3「仮定によるすり替え」を、 [3.3.1]は要素 $3 「 人$ 的エラーに至った内的要因」、細 目 3 「決定」.1「方針選択ミス」を示す。

操船者が他船を識別し、衝突のおそれに継続して気 付いているにもかかわらず、記憶や当て推量といっ た仮定によって情報を処理して正しい行動を取らず “いつものようにいずれ他船が避航するだろう”あ
るいは “自船が避航したからいずれ衝突のおそれは なくなるだろう”といったルールベースの行動を取 り、漫然とやり過ごしたり、忘れて衝突に至る場合 である。

\section{(3) $\{1.4 .1,3.1 .2,5.2 .3\}$}

[1.4.1]は要素 1「人的エラーをもたらした原因」、 細目 4 「非外的なことがら」.1「無意識の行動」を、 [3.1.2]は要素 3「人的エラーに至った内的要因」、 細目 1 「検出」.2「気づかず」を、[5.2.3]は要素 5 「パフォーマンスに影響する因子小、細目 2 「知的負 荷設備」.3「不適切な教育」を示す。

操船者の無意識的な条件反射的行動(スキルベー ス行動)やパタン化されたルールベース行動をきっ かけとして、衝突の恐れのある他船を見落としたり、 衝突のおそれに気付かない場合で、これは航行海域 や気象海象が操船に及ほす影響を操船者に十分に教 育していないことと関係している。

\section{(4) $\{1.4 .2,2.1 .4,5.2 .4\}$}

[1.4.2]は要素 1 「人的エラーをもたらした原因」、 細目 4 「非外的なことがら」2「意識的行為」を、[2.1.4] は要素 2 「人的エラーのメカニズム」、細目 1 「識別」.4

「慣れているパタンの見落とし」を、[5.2.4]は要素 5「パフォーマンスに影響する因子」、細目 2「知的 負荷設備」.4「不適切な訓練・手引書」を示す。

操船者は他船の存在には気づいていたものの他船 の行動を過去の経験から予測して“このままでも衝 突はしないだろう”とその後の他船の動向に意識的 に注意を払わない場合で、操船者の技能を向上させ るための訓練や手引書の不備と関保がある。

このように事故との相関が特に強いカテゴリーの 組み合わせはから「注意散漫による事故」は、操船 者のスキルベース行動、ルールベース行動による当 直モラル(状況認識 : Situation Awareness)の問題で ある場合が多いことがわかる。

\subsection{1 注意散漫による事故の防止}

事故防止のためには、数量化類による分析によ って得られた、事故と相関の強い操船者エラーの発 生を防ぎ、また発生したエラーが事故に結びつかな いような対策を講じる必要がある。そこで次の内容 を含んだ船橋当直実務指針(ガイドライン)を作成し、 そのガイドラインに基づく充実した訓練が重要であ る。（）内は関係するカテゴリーグループを示す。

（1）船舶交通の状況に応じた継続的な見張り

特に船首を横切る体勢の他船、自船の旋回径、 
停止距離を考慮した避航限界に侵入しそうな他船 の方位変化監視の徹底 (A, B, C, D, F, G, M, P, Q)

(2) レーダターゲットの常時 ARPA 捕捉

特に船首を横切る体勢の他船、自船の旋回径、 停止距離を考慮した避航限界に侵入しそうな他船 の DCPA 変化の監視

気象海象によるロストターゲットを防ぐための レーダ調整及びレンジ切換え

$$
\text { (A, B, C, D, F, G, M, P, Q) }
$$

（3）標淮的な避航条件の設定

自船の旋回径、停止距離を考慮して、避航動作 を取るための標準的な避航条件(DCPA、TCPA) の設定

（4）当直中の当直業務以外の作業の禁止

衝突の恐れのある他船はいないと臆断し、他の 作業に従事しない。

$(A, G, Q)$

（5）他船行動の臆断

方位変化がない場合は衝突のおそれがあると判 断し、他船の行動を不必要に予測したり期待した りしない。

(E, F, P)

\section{2 不湆当なタイミングによる事故と操船者エラー}

5.1 と同様に、次の(1) (3)のカテゴリーの組み合 わせは (Table 2 の網掛け)、事故と相関が特に強い と思われる。

(1) $\{2.2 .3,3.2 .2,5.3 .3\}$

[2.2.3]は要素 2 「人的エラーのメカニズム」、細目 2 「入力情報の処理」3「仮定によるすり替え」を、 [3.2.2]は要素 3「人的エラーに至った内的要因」、細 目 2 「確認」2「過小に反応」を、[5.3.3]は要素 5 「パ フォーマンスに影響する因子」、細目 3 「感情的因子」

3「時間的切迫」を示す。

操船者が他船を識別し、衝突のおそれに継続して 気付いているにもかかわらず、仮定によって情報を 処理して、大丈夫と思いこみ(過小に反応)正しい避 航動作を取らない場合で、時間的な切迫感と関係し ている。

\section{(2) $\{1.1 .2,3.1 .4\}$}

[1.1.2]は要素 1「人的エラーをもたらした原因小 細目 1 「外的なことがら」 2 「第 3 船による混乱」を、 [3.1.4]は要素 3「人的エラーに至った内的要因」、細 目 1 「検出」4「一点集中」を示す。

操船者が衝突の危険のある船舶とは別の第 3 船に のみ注意を奪われ、危険な状態に気付かない場合で ある。
(3) $\{2.1 .1,3.1 .2\}$

[2.1.1]は要素 2「人的エラーのメカニズム」、細目 1「識別」 1 「慣れによる一点集中」を、[3.1.2]は要 素 3 「人的エラーに至った内的要因小、細目 1 「検出」 2「気づかず」を示す。

操船者が “いつものように衝突のおそれのある他 船はいないだろう”と見張りを点り、他船を検出し ても衝突の危険に気付かない場合である。

このように不適当なタイミングによる事故は、注 意散漫による事故と同様に操船者の当直モラルに起 因する場合もあるが、当直者の状況認識能力では処 理できない状況に宿った場合に多く発生していると 考えられる。

\subsection{1 不冝当なタイミングによる事故の防止}

5.1 .2 亡同様に、事故防止のために次の内容を含ん だ船橋当直実務指針(ガイドライン)を作成し、その ガイドラインに基づく充実した訓練が重要である。 （）内は関係するカテゴリーグループを示す

（1）適切な人員配置での当直体制

航行海域や夜間、視界不良といった航行環境、 当直者の能力に応じて適切な人員配置で当直体制 を維持する。(A, B, C, E, G, H, J, K, N, M, P, Q )

(2) BRM の実施

複数の人員で当直を実施する場合の適切な $\mathrm{BRM}$ の実施 (A, F, I, O, P)

（3）時間的切迫と衝突の危険度評価

スケジュールの遅れ等で時間的切迫感があると、 他船との衝突の危険を過小評価する傾向があるた め、安全を最優先とする教育が必要である。

$(\mathrm{E}, \mathrm{H}, \mathrm{N}$,

（4）船舶輻輳、夜間における衝突の危険度評価 船舶輻辏海域や夜間航行の場合、操船者は他船 との衝突の危険を過小評価する傾向があるため、 見張りの増員、ARPA での他船監視を厳格に行う 必要がある。

$(\mathrm{E}, \mathrm{H}, \mathrm{N})$

（5）視界不良時における避航動作

視界不良時、レーダのみで他船を探知し避航す る場合、予防法の航法に違反した操船をする傾向 があるため、規則に従った操船を行うよう教育・ 訓練を行う必要がある。

$(\mathrm{K}, \mathrm{Q})$

\section{6. おわりに}

数量化III類による衝突海難事故を分析した結果、 衝突海難事故と操船者の人的エラーの相関をカテゴ リープロット及びスコアで表現できた。 
今回の分析では主成分を 3 までしか求めていない が、主成分 3 までの累積寄与率(3までの主成分が力 テゴリー全体の変動情報を説明している割合)は注 意散漫による事故で 0.241 、不適当なタイミングに よる事故で 0.302 であり、今回の分析では全体の 3 割程度しか説明できていないことになる。今後分析 する主成分を增やし、事故全体を説明するための力 テゴリーグループを抽出するとともに、他の事故に ついても分析を進めなければならない。また数量化 四類の分析ではカテゴリーの配置も意味があり、プ ロット上で離れたグループは性格が異なるため、抽 出したカテゴリーグループとその配置を考慮しなが ら、船舶の安全運航に必要なガイドラインの策定を 考える必要がある。

\section{参考文献}

(1) 竹本孝弘他 : 衝突海難事故における人的エラー の分類について,日本航海学会論文集 第 106 号, 平成 14 年 3 月

（2）竹本孝弘他：衝突海難事故における人的エラー の発生形態, 日本航海学会論文集 第 110 号, 平 成 15 年 3 月

（3）大村 平:多変量解析のはなし, 日科技連, 1999 年 8 月

(4) 高等海難審判庁監修: 海難審判庁裁決例集第 26 巻～第 41 巻, 海難審判協会, 1986 2001

(5) (株)日本科学技術研修所：JUSE 統計パッケージ 多変量解析ユーザーズマニュアル・活用ガイドブ ック，2001年 2 月

(6)長谷川勝也 : ゼロからはじめてよくわかる多変量 解析, 株式会社技術評論社, 平成 16 年 3 月

\section{穴電店答}

山田孝三郎 :

不適当なタイミングによる避航に関して、操船者 がその船の性能を熟知していないのではないかとい う疑念がある。このような観点からの所見を伺いた い。

\section{竹本孝弘 :}

今回調查した海難事故例は、海難番判裁決例集か らデータを収集した。調查した 190 件の事故の中で 操縦性能を理解していなかったことが事故の要因と なったのは 1 件だけであるが、そのことが避航操船 と操縦性能の関係が低いことを示しているわけでは ない。気象海象や操舵角に応じた避航限界を把握し ておくことは、特に船舶輻輳海域や視界制限状態で 他船を避航する場合の重要な要素となる。その意味
から、停止惰力、反転惰力、旋回径といった標準的 な操縦性能試験に加えて、各舵角や船速に応じた旋 回性能試験、新針路試験等を実施し、そのデー夕を 基に標淮的な避航条件を設定しておくことが重要だ と考える。 